\begin{tabular}{|c|c|c|}
\hline \multirow{3}{*}{$\begin{array}{l}\text { EREM 74/3 } \\
\text { Journal of Environmental Research, } \\
\text { Engineering and Management } \\
\text { Vol. 74 / No. } 3 \text { / } 2018 \\
\text { pp. 15-33 } \\
\text { DOl 10.5755/j01.erem.74.3.19974 } \\
\text { ๑ Kaunas University of Technology }\end{array}$} & \multicolumn{2}{|c|}{$\begin{array}{c}\text { A Review of Ghana Research Reactor-1 (GHARR-1) Componen } \\
\text { Ageing Degradation Problems and Ways of Mitigation }\end{array}$} \\
\hline & Received 2018/08 & Accepted after revision 2018/09 \\
\hline & \multicolumn{2}{|c|}{ crossef http://dx.doi.org/10.5755/j01.erem.74.3.19974 } \\
\hline
\end{tabular}

\title{
A Review of Ghana Research Reactor-1 (GHARR-1) Component Ageing Degradation Problems and Ways of Mitigation
}

\section{F. Ameyaw, R. G. Abrefah}

Department of Nuclear Engineering, Graduate School of Nuclear and Allied Science, University of Ghana, P. O. Box AE 1, Kwabenya-Accra, Ghana

\section{E.0 Amponsah-Abu}

Nuclear Reactors Research Reactors, National Nuclear Research Institute, Ghana Atomic Energy Commission, P. 0. Box LG 80, Legon-Accra, Ghana

\section{Corresponding author:}

F. Ameyaw, Department of Nuclear Engineering, Graduate School of Nuclear and Allied Science, University of Ghana, P. O. Box AE 1, Kwabenya-Accra, Ghana

GHARR-1 facility is a miniature neutron source reactor with a rated power of $30 \mathrm{~kW}$. GHARR-1 was commissioned on $8^{\text {th }}$ March, 1995. The facility has been operating using the micro-computer closed loop system (MCCLS) and the control console (CC) for 19 years. Age-related degradation effects in safety-related systems of nuclear reactors are managed to prevent safety margins from eroding below the acceptable limits provided in reactors design. This paper, therefore, provides an update on managing the safety aspects of ageing of structures, systems, and components (SSC) of GHARR-1. Managing the safety aspects of research reactor ageing requires a proactive, systematic, and integrated ageing management approach for the coordination of all activities relating to control, monitoring, and mitigation of ageing degradation of SSC through the life cycle of GHARR-1. This paper outlines the ageing management programme and mitigation practices. Strategies for the ageing management include periodic safety reviews, design features for components and unit replacement, and succession planning. Information sharing with other operating organizations is one of the means considered by GHARR-1 to attain excellence. This paper again concisely reviews and integrates information developed by other ageing management studies and other available information related to understanding and managing age-related degradation effects.

Keywords: structures, systems and components (SSCs), integrated circuit, ageing management, GHARR-1, comparator circuit. 


\section{Introduction}

Ageing is a conventional technique where the features of systems, structures and components (SSCs) progressively alter with application or time (IAEA, 2016). Two classes of time-dependent modifications are encountered in research reactors such as GHARR-1: SSCs (physical ageing) degradation, i.e., the steady decline of their physical features; and SSCs (non-physical ageing) obsolescence, i.e., their becoming outdated compared with present standards, knowledge and technology. The physical ageing of GHARR-1 will ultimately culminate in deterioration of materials put through general conditions of service. These comprise usual states of operation based on which SSCs are necessitated to function and the anticipated operational occurrences based on which SSCs are requisite to continuing to properly operate. The outcome of the ageing accident conditions (design basis accidents and beyond design basis accidents) of GHARR-1 require item-by-item evaluation. A decrease or deficiency in the capability of SSCs to operate within their criteria for acceptance may be caused by deterioration of GHARR-1. Unless pre-emptive measures are ready and well-timed, and fitting remedial activities are ensured, the safety and application GHARR-1 will be affected. The safety margins given in the SSCs design diminish by physical ageing. Upon failure to detect the reductions in these margins, GHARR-1 safety could be impaired except if actions are taken to abate it before loss of operational ability occurs. During the life of GHARR-1, advanced technologies have come up leading to the introduction of new

\section{Fig. 1}

Change in the rate of failure over time (Ji, Pickert, Cao and Xing, 2013)

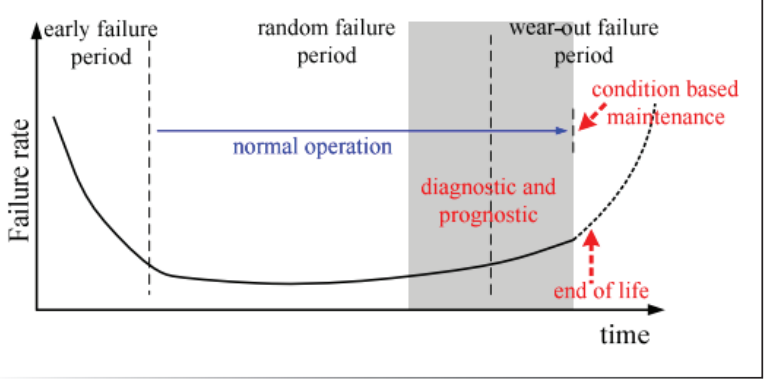

components or techniques and as a result difficulty in acquiring spare parts. Introduction of new components could also culminate in various failure modes (e.g., present day instrumentation contains microprocessors having failure modes that are different from their older components). Changes in standards and regulations may occur, which may require hardware or software changes and probably even interfering in the reactor operation.

The system or component failure probability is normally graphically demonstrated by the 'bathtub curve' shown in Fig. 1. Directly following a high occurrence of initial failures (primarily brought about in the course of the design, manufacturing and installation) is a substantial reduction in the likelihood of failure. The probability surges once again owing to the growing impact of the consequences of ageing. GHARR-1 ageing management has the objective of keeping a lower level failure rate. Monitoring systems and subsequent measures, i.e. maintenance, repair and replacement of components, start-up afore the commencement of a substantial failure rate rise just before the end of the technical life cycle. Ageing facilities are thus moving towards the edge of the bathtub curve. Technical adjustments and varying operational modes culminating in higher loads, notably power uprating, have the potential to raise failure rates. Therefore, for ageing reactors even a moderate rise in lifetime may cause a substantial surge in the frequency of failure, resulting in a loss of safety-related functions.

Ageing is a conventional technique where the features of systems, structures and components (SSCs) progressively alter with application or time (IAEA, 2016). Two classes of time-dependent modifications are encountered in research reactors such as GHARR-1: SSCs (physical ageing) degradation, i.e., the steady decline of their physical features; and SSCs (non-physical ageing) obsolescence, i.e., their becoming outdated compared with present standards, knowledge and technology. The physical ageing of GHARR-1 will ultimately culminate in deterioration of materials put through general conditions of service. These comprise usual states of operation based on which SSCs are necessitated to function and the 
anticipated operational occurrences based on which SSCs are requisite to continuing to properly operate. The outcome of the ageing accident conditions (design basis accidents and beyond design basis accidents) of GHARR-1 require item-by-item evaluation. A decrease or deficiency in the capability of SSCs to operate within their criteria for acceptance may be caused by deterioration of GHARR-1. Unless pre-emptive measures are ready and well-timed, and fitting remedial activities are ensured, the safety and application GHARR-1 will be affected. The safety margins given in the SSCs design diminish by physical ageing. Upon failure to detect the reductions in these margins, GHARR-1 safety could be impaired except if actions are taken to abate it before loss of operational ability occurs. During the life of GHARR-1, advanced technologies have come up leading to the introduction of new components or techniques and as a result difficulty in acquiring spare parts. Introduction of new components could also culminate in various failure modes (e.g., present day instrumentation contains microprocessors having failure modes that are different from their older components). Changes in standards and regulations may occur, which may require hardware or software changes and probably even interfering in the reactor operation.

\section{General experience and activities to deal with ageing}

With the intention of constraining the results of the damage ageing, pre-emptive activities were taken. Preferably, preventive works are set in the research reactor design phase. Pre-emptive activities are continuously ameliorated taking into account important experiences for operation and research results, and encompassed the following: appraising the productiveness of ongoing maintenance and refurbishment techniques and practices (encompassing restoration and occasional parts replacement) to limit components degrading due to ageing; formation of suitable conditions for functioning and practices that minimize ageing degradation of component implementation; and probable variations in design, materials or environmental conditions to reduce component ageing degradation. Occasional assessments of the GHARR-1 facility are handled at suitable lengths of time to ascertain actions and practices potency in thwarting SSCs deterioration due to ageing. There should be a regular review and record of resulting information. In the event that the efficacy of the pre-emptive activities established is seen to be unacceptable, suitable remedial activities are carried out.

Appraisal of a variety of investigation techniques is done to choose those approaches that are proper for sensing the outcomes of the ascertained procedure for ageing. Such inspection approaches encompass investigations, monitoring, operational tests, regular testing and non-destructive testing, including graphical inspection. By utilizing standard data accrued from preceding investigations, the examination outcomes are assessed to establish whether or not the state of the SSCs is satisfactory to safely continue to operate or corrective measures are essential. Added to the outcome of examination is the standard data to apply to examinations that follow, and records are kept of each corrective measure (International Atomic Energy Agency, 2008b). The ability and viability of detection approaches are regularly assessed to test their sufficiency (as well as whether they are adequately quick to respond, dependable and precise). The frequency of inspection of SSCS of GHARR-1 is in tandems with the designer and/or manufacturer suggestions. The failure probability of the SSCs based on the grounds of experience, involving skills obtained from similar facilities serves as a guide for the frequency of inspection. Suggested disparities of any kind to the examination frequency are acceptable. Examination efforts include surveillance of the state of SSCs (e.g., leaks, noise and vibration), which is usually performed during the research reactor's periodic walk through, and water coolant sampling for chemical or radiochemical assessment.

Effects of ageing of Ghana Miniature Neutron Source Reactor (MNSR) are detected among other things by a variation in operating parameters (e.g., control rod drop time, water chemistry parameters, temperature, flow rate and pressure) that are measurable. Ageing degradation likely predictive parameters are routinely monitored. Figures are evaluated and leanings ascertained to forecast the commencement of ageing 
deterioration in a well-timed way.

Effects of ageing are also sensed by verifying the operations of SSCs. The outcomes of test operations assumed as part of the maintenance programme of the MNSR are regularly inspected for evidence of learnings that show ageing degradation. The outcomes of the regular testing done to validate the agreement with the limits and conditions of operation are assessed to identify and appropriate conditions that are uncharacteristic before they give rise to safety significant results. Non-destructive testing techniques are also utilized to identify degradation due to ageing. Additional non-destructive testing approaches and techniques information that can be applied to detect ageing of SSCs in research reactors are established in reference (International Atomic Energy Agency., 2006).

\section{Ageing management programme}

\section{Management responsibility and structure}

The National Nuclear Research Institute (NNRI) is the Operating Organization (00) of the Ghana Research Reactor-1 facility, which is owned by Ghana Atomic Energy Commission (GAEC). The reactor is operated by staff of Nuclear Reactors Research Centre (NRRC) for and on behalf of the Director of NNRI. The Nuclear Regulatory Authority of Ghana, established by Legislative Instrument, Act 895 of 2015 of the Republic of Ghana, is the regulatory body. The Director of NNRI appoints responsible officers to constitute the Reactor Safety Committee (RSC) to review and make recommendations on reactor and radiological safety of the facility to the Reactor Manager (RM). The RM is responsible for the approval of operating procedures, after a review by the Safety Committee. The operating procedures periodically are made available to the Regulatory Body for its assessment and consideration before it is used (IAEA, 2010).

\section{Scope of ageing management}

The management of physical and non-physical ageing of SSCs is the main focus of the ageing programme for GHARR-1 ageing management. Ageing is a general process in which the characteristics of SSCs gradually change with time as the reactor is being used. Two kinds of time dependent changes research reactors encounter are the following: degradation of SSCs (physical ageing), i.e., gradual deterioration in their physical characteristics; and obsolescence of SSCs (non-physical ageing), i.e., their becoming out of date in comparison with current knowledge, standards and technology. The major components of an ageing management programme are operational procedures, maintenance procedures, periodic testing and inspection procedures, radiation protection procedures, utilization and modification procedure, and administrative procedures.

\section{Elements of ageing management programmes}

Ageing management programmes for GHARR-1 research reactors are aimed at identification and implementation of effective and appropriate ageing management actions and practices that provide for timely detection and mitigation of ageing effects in SSCs. A systematic ageing management programme for the research reactor is applied, comprising the following elements: screening of SSCs for ageing management review; identification and understanding of ageing degradation; minimization of ageing degradation; detection, monitoring and trending of ageing degradation; mitigation of ageing degradation; continuous improvement of the ageing management program; and record keeping. The ageing management program is applied at all stages during the lifetime of the research reactor, including the design stage.

\section{Screening of SSCs for ageing management review}

A research reactor has a large number and variety of SSCs with different safety considerations and susceptibility to ageing degradation. It is neither practicable nor necessary to evaluate and quantify the extent of ageing degradation in every individual SSC. A systematic approach is therefore applied to focus resources on those SSCs of GHARR-1, including experimental devices that can have a negative impact on the safe operation of the reactor and that are susceptible to 
ageing degradation (IAEA, 2008b). The safety-based approach outlined is applied to the screening of SSCs for a review of the management of ageing as follows:

First level screening focuses on the existing list of SSCs important to safety, which was developed during the design stage and reviewed for completeness. If such a list is not available, first level screening is performed to identify those SSCs that are important to safety, on the basis of whether or not failure could lead (directly or indirectly) to the loss or impairment of a safety function;

In the second level screening, for each of the SSCS identified as being important to safety, the specific structural elements and components that are important to safety are identified, i.e., those elements and components the failure of which could lead (directly or indirectly) to the loss or impairment of a safety function;

In the third level screening, from the list of structural elements and components important to safety, those for which ageing degradation has the potential to cause component failure are identified, and a justification provided for the components that are excluded.

An outline of this screening process is given in Figure 2.

\section{Identification and understanding of ageing degradation}

To understand the ageing degradation of a structure or component of the GHARR-1 facility, it's ageing mechanisms and effects are identified and understood; understanding ageing is the basis for the effective monitoring and mitigation of ageing effects. Existing methods for inspection, testing, surveillance, monitoring and assessment are evaluated, with account taken of relevant operating experience and research results, to determine whether they are effective for timely detection of ageing degradation before failure of the structure or component occurs (Alcala, 2001).

\section{Fig. 2}

Outline of the process for screening SSCs for ageing management (IAEA, 2010)

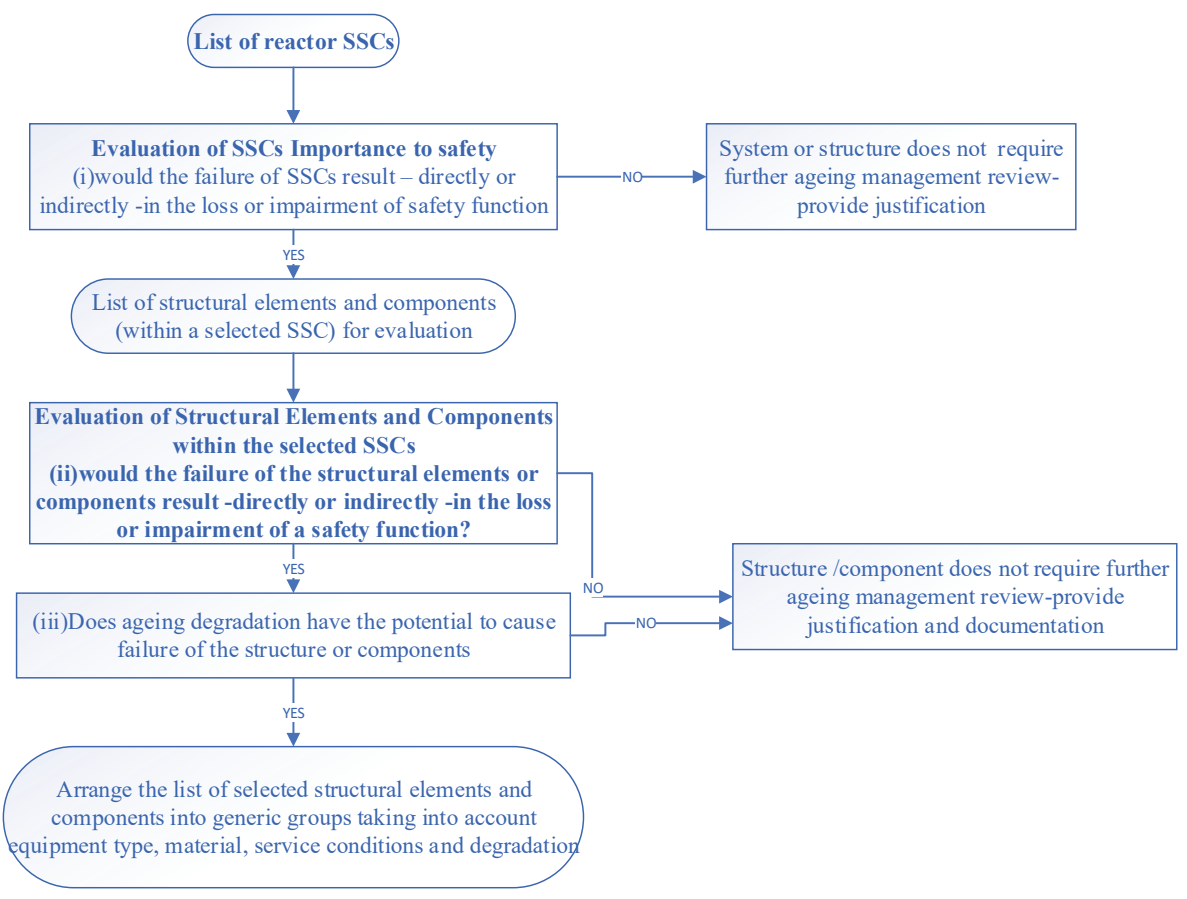




\section{IAEA guidelines and their use in GHARR-1}

To assist IAEA Member States in understanding ageing of SSCs important to safety and in effective ageing management of these SSCs, the IAEA in 1989 initiated a project on safety aspects of NPP ageing. The Safety Practices Publication Data Collection and Record Keeping for the Management of Nuclear Power Plant Ageing provides information on data requirements and a system for data collection and record keeping for the Ghana MNSR (Akaho, Anim-Sampong and Dodoo-Amoo, 1995). This project integrates information on the evaluation and management of safety aspects of reactor ageing generated by Member States into a common knowledge base, and derives guidance and assists Member States in the application of this guidance (International Atomic Energy Agency, 1990, 1991, 1992, 1992b, 1999; Kang and Moore, 2013).

General data needs grouped into three categories (baseline data, operating history data, and maintenance history data) are illustrated by several examples of component-specific data requirements. Actual record keeping systems, including an advanced system, are also described in the publication. Managing physical ageing of GHARR-1 components important to safety requires predicting and/or detecting when a reactor component will have degraded to the point that the required safety margins are threatened and taking appropriate corrective or mitigatory actions (IAEA, 1990). The methodology for the management of ageing of reactor components important to safety is documented in and consists of three basic steps: selecting, from the safety perspective, plant components in which ageing should be evaluated, by assessing the effects of ageing degradation on the ability of the components to perform their design functions and crediting existing programs and activities that manage ageing effectively; and performing ageing management studies for the selected components to determine appropriate ageing management actions (IAEA, 1990). The two-phased method for ageing management studies reviews current understanding, monitoring and mitigation of the components' ageing, and identifies or develops effective and practical technology and practices for its monitoring and mitigation.
The results of the ageing management studies were utilized to take appropriate management actions (i.e., improving existing operations and maintenance practices and the design) and to improve relevant codes, standards and regulatory requirements.

Development of the above consensus guidance is beneficial in its own right because it provides opportunities for practitioners from organizations with both direct and indirect responsibility for nuclear safety to address, in an interactive environment, important issues of common interest and to learn from each other. However, it is the actual application of guidance that has a positive impact on nuclear safety. The IAEA therefore devotes significant effort in assisting Member States in the application of its guidance. To assist Member States in the application of the above ageing management methodology, the IAEA in 1989 initiated pilot studies on management of ageing of nuclear power plant components, with four safety significant components selected for the studies (IAEA, 1991). These four components represented different safety functions and materials susceptible to different types of ageing degradation. The components selected were the primary nozzle of a reactor pressure vessel, motor operated valves, concrete containment building and instrumentation and control (I\&C) cables.

Phase 1 studies were completed via Technical Committee meetings held in 1990 and 1991 and consisted of paper assessments of the current state of knowledge on age-related degradation, its detection and mitigation, and recommendations for Phase 2 studies. Separate coordinated research programmes were set up for each of the above four components to implement the Phase 2 pilot studies. The overall objective of each pilot study was to identify the dominant ageing mechanisms or processes (frequent mechanisms of SSCs ageing, such as corrosion, radiation, temperature, pressure, etc., and it is worth noting that ageing is often caused by two or more mechanisms jointly) that lead or culminate in ageing and to develop an effective strategy for managing ageing effects caused by these mechanisms or processes. Table 1 provides summary information on specific ageing mechanisms. 
Table 1

Information on specific ageing mechanisms (IAEA, 1995)

\begin{tabular}{|c|c|c|}
\hline Conditions & Ageing mechanism & Consequences/failures \\
\hline 1 & 2 & 3 \\
\hline Radiation & Change of properties & $\begin{array}{l}\text { Chemical decomposition } \\
\text { Strength change } \\
\text { Ductility change and colour change } \\
\text { Swelling and resistivity change } \\
\text { Burn-up }\end{array}$ \\
\hline Temperature & Change of properties & $\begin{array}{l}\text { Strength change } \\
\text { Resistivity change } \\
\text { Ductility change } \\
\text { Colour change }\end{array}$ \\
\hline Stress (pressure) & creep & Changes of geometry (e.g., break, collapse) \\
\hline Cycling of temperature, flow and/or load & Motion & $\begin{array}{l}\text { Displacement } \\
\text { Change of position or set point } \\
\text { Loose connections }\end{array}$ \\
\hline Flow induced vibrations & $\begin{array}{l}\text { Fatigue } \\
\text { Wear }\end{array}$ & $\begin{array}{l}\text { Break, collapse and deformation } \\
\text { Deterioration of surface } \\
\text { Change of dimensions }\end{array}$ \\
\hline Flow & Erosion & Strength change \\
\hline Fluids chemistry & Corrosion/galvanic cells & $\begin{array}{l}\text { Release of radioactive material } \\
\text { Strength change } \\
\text { Deposition of particles } \\
\text { Shorts circuits } \\
\text { Leakage conditions }\end{array}$ \\
\hline
\end{tabular}

\section{Mitigation practices and strategies for ageing management}

The practices necessary to manage the nuclear reactor ageing are elaborate, beginning with design and analysis and extending to a variety of maintenance and research activities. This section reviews the safety practices used to manage GHARR-1's ageing. GHARR-1 attained criticality on December 17, 1994, and has since then been in operation (IAEA, 199). With over fourteen years of operation, several experiences have been obtained in the continual operation of GHARR-1. Due to ageing, some components have been replaced to ensure efficient operation of the facility. The microcomputer closed loop system has been replaced once and it currently has several capabilities that were absent in the 1994 model. Some resistors, capacitors, bulbs, integrated circuits, fuses, dry cells and other components have been replaced to ensure efficient use of the facility. On the control rod drive mechanism, several replacements of auto-synchronization, bearings, potentiometers and limit switches have ensured proper operation of the system. Electromagnetic coils had to be rewound for smooth operation of the drive mechanism. Two different sessions of beryllium plate addition have been performed to compensate for reactivity loss due to samarium poisoning and fuel burn-up. The strategies for ageing management based on the QA Programme stem from identification and selection of components the ageing of which has a high impact on safety performance (IAEA, 1999): review of design-basis safety margins, qualification testing, operating experience, expert opinions, development of methods for surveillance, inspection, monitoring, and maintenance; and engineering studies including verification of inspection, surveillance, 
monitoring, and maintenance methods, in-situ examinations, collection of data from operating equipment, post-service examinations, tests of naturally-aged equipment, and cost-benefit analyses. Programmes for periodic assessment based on broad operational data collection, programmes for preventive maintenance, continuous monitoring of the reactor's components, feedback from incident analyses, individual and component qualification, personnel education and training, external control and quality assurance are the other avenues used to ensure safe operation of the reactor. The collection and evaluation of operational data likewise receive more attention. A computerized data collecting system is in place for operational records. Operational feedback is used to develop test specifications for electrical and other equipment. Corrosion of the cladding of the fuel element and other internal structural components in the reactor vessel is prevented by ensuring good water quality.

\section{Periodic safety reviews}

The objective of the ageing management review in a periodic safety review is "to determine whether ageing in GHARR-1 is being effectively managed so that required safety functions are maintained, and whether an effective ageing management programme is in place for future plant operation" (Odoi et al., 2011). The ageing management review within a periodic safety review therefore aims to establish the following: whether for each SSC important to safety all significant ageing mechanisms have been identified; whether there is a thorough understanding of the relevant ageing mechanisms and their effects; whether the ageing behaviour of SSCs over the period of operation to date is consistent with predictions; whether there are adequate margins in respect of ageing to ensure safe operation for at least the period until the next periodic safety review is due for completion; whether there is an effective ageing management programme (addressing operations, chemistry, maintenance, surveillance and inspection) in place for future plant operation.

Possible outcomes of the ageing management review within the periodic safety review are improvements to the scope, procedures and/or frequency of maintenance, surveillance and inspection, and modifications of operating conditions or design (including possible changes of the design basis of structures and components). Safety reviews are performed regularly to ensure adherence to regulations in use at the reactor operations. There is regular evaluation of operational activities by staff of NNRI. The Reactor Safety Committee as well as the Radiation Safety Committee perform regular reviews of the safe practices at the Centre and provide their findings to the Director of NNRI for the necessary actions to be taken. RPB also conducts a series of inspections to ascertain the level of adherence to their regulations. NNRI hosted an IAEA team of experts for an Integrated Safety Assessment of Research Reactors (INSARR) Mission as part of the Regional Workshop on Review and Assessment of Research Reactor Safety Documents for African Countries hosted by the Institute in November 2008 (Novak and Bulletin, M Podest, 1987). The Follow-up Mission was held from $4^{\text {th }}$ to $6^{\text {th }}$ May 2009 (IAEA, 2013). The visit afforded NNRI the opportunity to have a comprehensive review of both documents and activities that bother on safe practice.

\section{Constraints}

1 An ageing management programme requires money and human resources. Justification of expenditure, supported by cost benefit and risk analysis, should comply with the utility business planning process to ensure approval. (Note: this statement assumes that should an ageing management programme be required to support nuclear safety then this will be consistent with the targets of business; however, the justification for expenditure will still probably have to be presented in accordance with the planning process).

2 It is unlikely, although not impossible, that the business organization will be significantly changed to meet the needs of an I \& C ageing management strategy. Where possible, the process uses established procedures and lines of communication. Careful judgment is required when any new process is proposed. Motivation of staff is vital and they must be convinced of the benefit of a new approach to maximize its chance of success. It is to be emphasized that this applies to all staff involved in the process, from the first line maintenance technicians to managers.

3 In many cases, the strategy will require the prediction of future performance based on no historic data. There 
may be established procedures for such judgments, usually in the form of risk assessments, but in many situations, this will not be the case.

4 Ageing issues are usually reactor specific and input from experienced staff is vital. However, such staff may only be available for short, unpredictable periods of time. It is vital that the use of these staff is controlled to gain maximum benefit. Ideally, staff will be taken out of line, but if this is not possible, time must still be set aside to ensure that their views, opinions and experience are captured.

5 The particular ageing management strategy selected must be appropriate for the safety relevance of the system concerned. The IAEA (2008) defines the categories of safety relevance of nuclear reactor systems.

6 The regulator requires safety margins to be preserved and that the programme is being undertaken in accordance with a system methodology.

7 Options for the support of existing equipment will be constrained by what happens to the equipment suppliers. The extent of support for and knowledge of older ranges of equipment will generally reduce as product ranges develop. In some cases, companies will cease to trade altogether causing a loss of design knowledge and support. This may have severe consequences for some reactor systems (e.g., reactor protection systems).

\section{Consideration of ageing during design}

Ageing management began with the design process for the reactor. Many design criteria explicitly or implicitly address ageing. The inclusion of the aluminium tray to house beryllium shims to compensate for reactivity loss due to fuel burn-up and samarium poisoning is a typical example of this design consideration. The working temperature of GHARR-1 is 15$60^{\circ} \mathrm{C}$ and, because it is operated with frequent starting and shutdown steps, the fuel cladding is sensitive to pitting corrosion, which could affect the integrity of the cladding (IAEA, 2010). The measures that have been put in place to prevent pitting corrosion are that the technique of the quench natural ageing process and the anode coating process was adopted to create an oxide film of 10-15 $\mu \mathrm{m}$ in thickness and control of water quality.

\section{Design features for component replacement}

A crane rail runs the large access door over the reactor pool to the roof wall of the reactor hall. The rail carries a crane of lifting capacity of 3 tons and height $13.5 \mathrm{~m}$ from the bottom of the pool. This crane is used to have access to the pool as well as the vessel that houses the core for fuel replacement, repairs and any other activity that shall be required in the lifetime of the core.

Two manual hoists of one ton and two tons capacity each are located on the ceiling $7.65 \mathrm{~m}$ above the floor level of the water purification room. Each of the hoists is used for services with the pool/reactor water purification systems. A one-ton manual hoist is located on a rail centrally placed above the temporary waste storage pit for removal of the concrete covers over the waste storage area.

The reactor vessel is divided into two sections. This is to facilitate the installation of the reactor core and the core replacement after its useful life. During core replacement, the upper section of the vessel is removed and the lower section is supported by four long rods while refuelling can be conducted under water. This two-section design of the reactor vessel facilitates the removal of the core from the reactor after its useful life without any loss of shielding. Before the two sections are separated, the core is made subcritical by insertion of cadmium rabbits. The central control rod and cable, the irradiation tubes and instrument lines are then removed from the reactor.

The lower and upper container sections are disconnected and separated under water using a long handling tool. The upper section is then removed sideways to get access to the reactor core and reflector assembly. The core can then be transferred into the reactor pool or the shielded shipping container and a new core replaced for the start of the re-commissioning programme.

\section{Ageing mitigation with performance upgrades}

The microcomputer closed loop system was replaced in 2008 with a current upgrade of the component. The new version provides the neutron flux, inlet and outlet temperatures, control rod position, pre-set options, 
data analysis tools and a lot more features that allow for an interactive use of the system.

The control rod drive mechanism has been replaced with a newer version. The installation was performed by the staff of GHARR-1. The procedure that was reviewed by the Reactor Safety Committee and approved by the regulator was used in the replacement exercise. Efforts are currently underway to upgrade the chilling unit at the facility. This upgrade is expected to help in reducing the temperature in the core during operation so that the effect of temperature on reactivity can be reduced.

\section{Top beryllium shim addition}

Long term reactivity control is exercised by periodically increasing the thickness of this reflector to compensate for the reactivity loss caused by fuel burn-up and samarium poisoning. The top reflector is of variable thicknesses and is assembled by stacking semi-circular plates within an aluminium tray. It is composed of a group of semi-circular beryllium shims with internal diameter of $243 \mathrm{~mm}$. Four different thicknesses are available, $1.5 \mathrm{~mm}, 3.0 \mathrm{~mm}, 6.0$ $\mathrm{mm}$ and $12.0 \mathrm{~mm}$. Two different sessions of top beryllium shim additions were performed at the facility. The first was held in March 2002 and the recent one was in April 2009. In both cases, $3.0 \mathrm{~mm}$ thickness of the beryllium shims was added. These activities have helped to maintain the reactor's core excess reactivity at $4 \mathrm{mk}$. The continuous addition of the beryllium shims has enabled NNRI to keep the reactor beyond the core life of 10 years.

\section{Succession planning}

In accordance with Article 3 of Act (2000) which mandates the Commission to collaborate with the Universities in training and teaching in the field of nuclear energy, Ghana Atomic Energy Commission (GAEC) with the University of Ghana and the IAEA has established a Postgraduate School of Nuclear and Allied Sciences (SNAS) to train personnel for Ghana's nuclear practice and the Africa Region. The objectives are to preserve and enhance knowledge in nuclear technology and to develop human and institutional capacity in the field of nuclear and allied sciences. The following MPhil and PhD Courses are offered: Nuclear Engineering, Applied Nuclear Physics, Nuclear and Environmental Protection, Radiation Protection, Nuclear Agriculture, Medical Physics, Nuclear and Radiochemistry among others. Hence, with these arrangements in place, sustainable human resource development (HRD) is assured. The students from this school are trained on practical approaches to solving problems. This kind of approach coupled with the support of both the Government and the IAEA can go a long way in preparing human resources to carry on with the operation of the facility as well as the future nuclear power programme of the country. Other countries are invited to patronize the school and collaborate with us to train students into efficient nuclear scientists (IAEA, 2014; Wogman, Bond, Waltar and Leber, 2005).

\section{Ageing of documentation}

The extent of ageing-related observation. The ageing-management in nuclear reactors is extended to the plant documentation that, within the framework of planning, assembly, commissioning, operation and decommissioning of a nuclear reactor, is created and archived with the following goals: demonstrating the existence and the fulfilment of legal prerequisites; describing the required condition of GHARR-1 and describing the essential procedures during assembly and operation of the plant; enabling an assessment of the actual condition of the GHARR-1 facility; presenting the information required for a safe operation of the facility, and enabling experience feedback.

There are a few ageing aspects to be ensured. The documentation of the GHARR-1 facility is to be kept up-to-date. This requires that organizational directives be established regarding the preparation and modification of documents. It is noteworthy that the term documentation comprises all forms of lasting data storage, be it in the form of, e.g., electronic data or printed media. The availability of the documentation is ensured. This pertains to providing a location for the documentation that is suitable to its usage and storage and pertains, as well, to the employment of data storage media enabling a sufficiently speedy and efficient access to the contents of the documents. The legibility of the documentation is to be such that its 
contents is conveniently accessible to the user. Of particular importance in this respect are the physical conditions of the documentation as well the availability of technical equipment for a suitable reproduction of the contents of the documents. When transferring documents to other data media, the contents of the documents has to remain unadulterated. The documentation's availability and legibility are normally tested by suitable procedures (e.g., random visual tests and random testing of the readability of data media). In the case that defects are detected in the documentation, these are removed within a reasonable length of time in accordance with the respective document's significance regarding a safe reactor operation.

The general requirement for documentation of data from the information systems and operation management systems is that the information systems and operation management systems in nuclear reactors be used for supporting organizational processes and documenting data and procedures. The extent of ageing-related observation is as follows: the ageing-management in GHARR-1 is extended to those data processing systems that influence the condition of safety-related systems or that record their condition; data associated with processing systems directly used for process surveillance and control are not part of the extent of ageing-related observation.

The requirements for the recording of data are as follows: depending on the requirements for the recording of data in nuclear reactors, the data stored by data processing systems shall remain available over long periods of time. In this respect, administrative regulations and procedures are established to ensure that the relevant databases are backed up, the resulting data storage media are suitably handled and stored and the relevant data storage media remain readable; the integrity of the data stored in data processing systems is ensured. In this respect, administrative regulations are established regarding the updating and maintenance of the database.

\section{Operation}

The following issues should be considered in implementing an effective and systematic ageing management programme: adequate and committed support for the ageing management programme by the management of the operating organization (NNRI) will enhance an effective ageing management programme;

early implementation of solutions to ageing problems is very important and must be tackled with all seriousness;

a proactive approach based on an adequate understanding of SSC ageing, rather than a reactive approach responding to SSC failures;

optimal operation of SSCs to slow down the rate of ageing degradation;

proper implementation of maintenance and testing activities in accordance with operational limits and conditions, design requirements and manufacturers' recommendations, and following approved operating procedures (IAEA, 2010; Glasstone and Sesonske, 2010); minimization of human performance factors that may lead to premature degradation, through enhancement of staff motivation, sense of ownership and awareness, and understanding of the basic concepts of ageing;

availability and use of correct operating procedures tools and materials, and of a sufficient number of qualified staff for a given task;

appropriate storage of spare parts and consumables susceptible to ageing, to minimize degradation while in storage and to control their shelf life properly;

availability of the necessary competences for dealing with complex ageing issues;

effective internal and external communication;

feedback of operating experience (both generic and plant specific operating experience, including operating experience from non-nuclear plants);

follow-up of possible degradation trends in SSCs between successive periodic testing;

use of databases on SSC reliability and maintenance histories;

use of adequate and qualified methods of non-destructive testing and ageing monitoring for early detection of flaws possibly resulting from intensive use of equipment (IAEA, 2010). 
The operating organization should identify and address the following potentially significant common weaknesses of ageing management: insufficient understanding and predictability of ageing at the time of design and construction of a research reactor; and premature ageing of SSCs in research reactors (i.e., ageing degradation that occurs earlier than expected) caused by non-compliance with the requirements of the management system, unforeseen ageing phenomena, or operation of SSCs beyond their design specifications or in service conditions more severe than the normal environmental conditions.

The operating organization should identify and justify possible changes in operational conditions (e.g., radiation levels, flow distribution, coolant velocity and vibration) that could cause accelerated or premature ageing and failure of some SSCs, in the event of uprating of the reactor power, installation of new experimental devices or changes in the utilization programme, implementation of modifications, including changes to safety analysis, and replacement of SSCs.

If a new ageing mechanism is discovered (e.g., through feedback from operating experience or research), the operating organization should perform an appropriate review of the ageing management programme to determine the effects, if any, on SSCs important to safety which are operating at similar conditions; the operating organization should put in place appropriate ageing management measures. For SSCs important to safety, the operating organization should consider preparing contingency maintenance plans to deal with the potential degradation or failure of these SSCs caused by potential ageing mechanisms and effects.

\section{Existing and future means to share information}

To ensure the safety of GHARR-1, the Nuclear Regulatory Authority performs a variety of activities, including development and documentation of the licensing bases that specify plant design requirements and operation and maintenance (O\&M) practices, inspection and enforcement of license requirements, performance of technical research and analysis, and modification of regulatory requirements as needed. Although the Nuclear Regulatory Authority plays a central role in assuring safety of the reactor, the primary responsibility for the safe operation of GHARR-1 rests on the National Nuclear Research Institute, the licensee. The NNRI is ultimately responsible for the design, operation, and maintenance of the reactor, not only to meet NRA requirements but to assure safety.

If an ageing detection programme is established shortly after a research reactor facility is placed into operation, no historical failure information will initially be available on actual facility components or systems. However, information from similar facilities or from research and test programmes will generally be available and should be utilized in setting management priorities in the programme. As operation of the facility progresses, data on ageing will become available. Periodic assessment of this data consistent with category and safety significance can yield information that can be used to evaluate the effectiveness of the programme. Modifications to the programme should be made based on recorded and compiled experience. Experts may be utilized to supplement in-house capabilities especially in the applications of specialized inspection techniques, and in the areas of interpretation of inspection and test results.

These may be engineers or scientists working in the nuclear industry, research and regulatory organizations which have knowledge and experience in nuclear research reactor performance and behaviour, or specialists from outside the nuclear industry. The IAEA has completed a Coordinated Research Program on Data Acquisition for Research Reactors PSA Studies with the objectives of developing a data collection system for research reactors and of generating research reactor specific reliability data for use in PSAs. Although the system is oriented to specific component failure data, the methodology can be useful for ageing related data collection (IAEA, 2008a). To pool resources, share experiences, and coordinate efforts, NNRI collaborates with the IAEA to provide technical assistance for the safe operation of GHARR-1. At the Operating Organization level, responsibilities that accompany the development and implementation of the Quality Assurance (QA) programme are based on the following principles: management of GHARR-1 provides means and support to achieve objectives; people perform work to achieve quality. 
Evaluation of the effectiveness of management processes and work performance. Maintenance and periodic inspections are the responsibility of the maintenance engineer of GHARR-1 who liaises with other sectional heads to accomplish tasks and appoint technicians to carry out the maintenance and inspection procedures under his supervision. Trained operators of the various systems are obliged to report all faults and outages of systems during operation, by completing the maintenance documentation forms for the respective systems. The verification of adherence to quality standards by means of periodic audits is performed by the Quality Assurance Coordinator and Management is involved in non-conformance control and the determination of corrective actions to curtail the recurrence of non-conformance to quality standards.

\section{Conclusion}

Ageing management procedures are integrated as part of the maintenance programme for GHARR-1.

\section{References}

Akaho, E., Anim-Sampong, S., \& Dodoo-Amoo, D. (1995). Safety Analysis Report for Ghana Research Reactor-1.

Alcala, R. (2001). Application of non-destructive testing and in-service inspection to research reactors. IAEA-TECDOC-1263, IAEA, Vienna.

Amponsah Abu E.O, Gbadago J.K, Addo M.A, Sogbadji R.B.M, Odoi H.C, A. A. . (2013). Ageing management and refurbishment of Ghana Research Reactor-1 (GHARR-1).

Ampornrat, P., Boonsuwan, P., Sangkaew, S., \& Angwongtrakool, T. (2017). Preliminary study of degradation from neutron effects of core-structural materials of Thai Research Reactor TRR-1/M1. Journal of Physics: Conference Series, 860(1), 12042. https://doi.org/10.1088/1742-6596/860/1/012042

Glasstone, S., \& Sesonske, A. (2010). Nuclear reactor engineering : reactor systems engineering (Vol. C).

IAEA. (1995). TECDOC-792, Research Reactor Ageing.

IAEA. (2010). Ageing Management for Research Reactors.

IAEA. (2016). laea Safety Glossary - Terminology used in nuclear safety and radiation protection. International Atomic Energy Agency, Vienna, 219.

International Atomic Energy Agency. (1990). SAFETY ASPECTS OF NUCLEAR POWER PLANT AGEING. IAEA-TECDOC-540.
After operation of GHARR-1 for over twenty years, the focus of the ageing management review was on maintaining and improving safety and on preventive and corrective maintenance including re-engineering, upgrading, classification of SSC in order to form a basis for setting priorities to securing preventive maintenance strategy for SSC with high safety and/ or operational importance, maintenance classification based on safety that take into account operability, computerized system important for planning and recordkeeping. A specific procedure was developed to review how the ageing phenomenon has to be treated from a safety point of view. This procedure was based on GHARR-1 ageing data sheets written on each mechanism, which leads to more consistent reports. This general method was adopted for longer lifetime extension in years with additional actions in different fields in order to validate such an extrapolation. Obviously, these actions are still in progress. This approach meets the IAEA Safety Guide NS-G-2.12c requirements.

International Atomic Energy Agency. (1992a). Manual on reliability data collection for research reactor PSAs. IAEA TECDOC-636.

International Atomic Energy Agency. (1992b). Pilot studies on management of ageing of nuclear power plant components Results of Phase I. IAEA-TECDOC-670.

International Atomic Energy Agency. (1999). IAEA Safety Reports Series, No.15. Implementation and Review of a Nuclear Power Plant Ageing Management Programme, 1999.

International Atomic Energy Agency. (2008). International Conference on Research Reactors: Safe Management and Effective Utilization.

International Atomic Energy Agency. (2011). Basic Principles Objectives IAEA Nuclear Energy Series Good Practices for Water Quality Management in Research Reactors and Spent Fuel Storage Facilities.

International Atomic Energy Agency. (2014). Project experiences in research reactor ageing management, modernization and refurbishment: report of a technical meeting on research reactor ageing management, modernization and refurbishment.

International Atomic Energy Agency. (1991). Data collection and record keeping for the management of nuclear power plant ageing : a safety practice. International Atomic Energy Agency. 
International Atomic Energy Agency. (1992). Methodology for the management of ageing of nuclear power plant components important to safety. International Atomic Energy Agency.

International Atomic Energy Agency. (2006). Maintenance, periodic testing and inspection of research reactors : safety guide. International Atomic Energy Agency.

International Atomic Energy Agency. (2008a). Operational limits and conditions and operating procedures for research reactors : safety guide. International Atomic Energy Agency.

International Atomic Energy Agency. (2008b). The operating organization and the recruitment, training and qualification of personnel for research reactors : safety guide. International Atomic Energy Agency.

International Atomic Energy Agency. (2013). Periodic safety review for nuclear power plants : specific safety guide. International Atomic Energy Agency.

Ji, B., Pickert, V., Cao, W. P., \& Xing, L. (2013). Onboard condition monitoring of solder fatigue in IGBT power modules. In Proceedings - 2013 9th IEEE International Symposium on Diagnostics for Electric Machines, Power Electronics and Drives, SDEMPED 2013 (pp. 9-15). https://doi.org/10.1109/DEMPED.2013.6645690

\section{Appendices}

\section{APPENDIX I: Ageing of instrumentation and control systems}

Most frequently reported I\&C components that failed due to ageing were electronic cards, relays, electrolytic capacitors, batteries, small power units, and switches. There were very few cases identified that involved passive I\&C components, i.e., instrumentation cables. Typical ageing degradation mechanisms associated with I\&C components were loss of capacity, loss of insulation resistance, set point drift, and wear (relays). There were many cases that the ageing degradation mechanism was not identified. It is believed that electrical failures (some may be ageing related) of certain small electronic components such as resistors, diodes, and electrolytic capacitors could be the cause. Growing whiskers were identified to have caused inadvertent electrical conductive connections and lead to malfunctions or short circuits on the affected I\&C components. Tin whiskers are electrically conductive mono crystals, which can grow out of tinnier surfaces even when they are coated. They reach lengths of several millimetres and in rare cases up
Kang, K.-S., \& Moore, J. H. (2013). IAEA Activities on Concrete Ageing in Containment and Other Structures in Nuclear Power Plants. In Volume 7: Operations, Applications and Components ( $p$. V007T07A024). ASME. https://doi.org/10.1115/PVP2013-97570

Novak, S., \& Bulletin, M Podest -, U. (1987). Nuclear power plant ageing and life extension: Safety aspects. laka.org. Retrieved from http://www.laka.org/info/kcb2034/bijlage_17.pdf

Odoi, H. C., Akaho, E. H. K., Anim-Sampong, S., Jonah, S. A., Nyarko, B. J. B., Abrefah, R. G., ... Boffie, J. (2011). Investigative studies on effect of reflector thickness on the performance of low enriched uranium-fueled miniature neutron source reactors. Nuclear Engineering and Design, 241 (8), 2909-2915. https://doi.org/10.1016/j.nucengdes.2011.05.019

Tcherner, J., Vaithilingam, L., \& Han, M. (2017). Effective Aging Management of NPP Concrete Structures. Journal of Advanced Concrete Technology, 15(1), 1-9. https://doi.org/10.3151/jact.15.1

Wogman, N. A., Bond, L. J., Waltar, A. E., \& Leber, R. E. (2005). The nuclear education and staffing challenge: Rebuilding critical skills in nuclear science and technology. In Journal of Radioanalytical and Nuclear Chemistry (Vol. 263, pp. 137-143). https:// doi.org/10.1007/s10967-005-0027-z

to 10 millimetres. Considering a number of sensitive components installed in different systems important to safety, the increase rate of failure could affect the overall plant risk profile. A common cause failure of more than one train or multiple inter-system failures may also occur.

\section{APPENDIX II: Ageing of GHARR-1 reactor pool water and other components}

The GHARR-1 reactor and pool water measurement are carried out every Monday in order to detect clad failure as early as possible. It is expected that fission products such as ${ }^{131-135} \mathrm{I},{ }^{90} \mathrm{Sr},{ }^{95} \mathrm{Zr},{ }^{95} \mathrm{Nb},{ }^{137} \mathrm{Cs},{ }^{140} \mathrm{Ba},{ }^{140} \mathrm{La}$, ${ }^{85} \mathrm{Kr},{ }^{133} \mathrm{Xe}$ and ${ }^{135} \mathrm{Xe}$ will be transferred through the failed clad to the reactor. Table 2 presents values obtained for the measurements of caesium-137 in the reactor and the pool water within the year 2011. Other elements were not detected. The obtained values for ${ }^{137} \mathrm{Cs}$ are lower than the minimum values stated by the Safety Analysis Report (SAR). According to the SAR, $3.4 \times 10^{5}$ $\mathrm{Bq} / \mathrm{L}$ of ${ }^{137} \mathrm{Cs}$ in the reactor and pool water, respectively, present minimum hazard (Amponsah et al., 2013). 


\section{Table 2}

Reactor and pool water values of caesium-137

\begin{tabular}{c|c|c}
\hline \multirow{2}{*}{ Date } & Reactor water & Pool water \\
\cline { 2 - 3 } & Activity (Bq/L) & Activity (Bq/L) \\
\hline $28-03-2011$ & 2 & 3 \\
\hline $04-04-2011$ & $3.53 \pm 0.51$ & $3.74 \pm 0.53$ \\
\hline $18-04-2011$ & $3.51 \pm 0.44$ & $3.40 \pm 0.48$ \\
\hline $09-05-2011$ & $2.48 \pm 0.44$ & $2.46 \pm 0.46$ \\
\hline $16-05-2011$ & $3.93 \pm 0.53$ & $3.86 \pm 0.64$ \\
\hline $30-05-2011$ & $4.41 \pm 0.60$ & $1.08 \pm 0.32$ \\
\hline $06-06-2011$ & $3.19 \pm 0.67$ & $2.85 \pm 0.46$ \\
\hline $10-10-2011$ & $2.04 \pm 0.39$ & $2.71 \pm 0.46$ \\
\hline $21-11-2011$ & $1.86 \pm 0.39$ & $3.58 \pm 0.46$ \\
\hline $19-12-2011$ & $2.25 \pm 0.37$ & $2.32 \pm 0.30$ \\
\hline
\end{tabular}

If water quality is not good enough, it will result in curd deposits on fuel cladding, which will affect the heat conduction properties of the fuel elements. Poor water quality will also increase pit corrosion. The pool water purification is therefore carried out on Mondays and the water quality is monitored. The monthly average resistivity values measured are converted to conductivity using equation 1

$$
C=1 / \rho(\mu S)
$$

where $\mathrm{C}=$ Conductance in $\mathrm{cm} / \Omega$ or $(\mu \mathrm{S}) ; \quad \rho=$ Resistivity in $\Omega$ or $(M \Omega)$

The permissible conductivity ranges for both reactor and pool water are 0.5-1.0 $\mu \mathrm{S}$ and 1.0-2.0 $\mu \mathrm{S}$, respectively, according to the SAR. Table 3 shows some measurements of reactor and pool water conductivity. Due to pump breakdown, measurement for water was not done in December 2011.

In the design of, and any modification to, a research reactor, including installation of new experimental devices or changes to existing equipment, consideration should be given to the needs of the operating organization with regard to ageing management and reactor utilization.

The design of, and any modification to, a research reactor or experimental device should facilitate inspections and testing aimed at detecting ageing mechanisms

Table 3

Reactor and pool water conductivity (International Atomic Energy Agency, 1992a)

\begin{tabular}{l|c|c|c|c}
\hline \multicolumn{1}{|c|}{ Month } & $\begin{array}{c}\text { Average reactor water } \\
\text { quality }(\mathrm{M} \Omega / \mathrm{Cm})\end{array}$ & $\begin{array}{c}\text { Conductivity of reactor } \\
\text { water }(\mu \mathrm{S})\end{array}$ & $\begin{array}{c}\text { Average pool water } \\
\text { quality }(\mathrm{M} \Omega / \mathrm{Cm})\end{array}$ & $\begin{array}{c}\text { Conductivity of pool } \\
\text { water }(\mu \mathrm{S})\end{array}$ \\
\hline \multicolumn{1}{c|}{1} & 2 & 3 & 4 & 5 \\
\hline January & 1.975 & 0.5 & 0.675 & 1.5 \\
\hline February & 1.200 & 0.8 & 0.720 & 1.4 \\
\hline March & 1.225 & 0.8 & 0.750 & 1.3 \\
\hline April & 1.913 & 0.5 & 0.733 & 1.4 \\
\hline May & 1.912 & 0.5 & 0.940 & 1.1 \\
\hline June & 1.938 & 0.5 & 1.068 & 0.9 \\
\hline July & 1.913 & 0.5 & 1.240 & 0.8 \\
\hline August & 2.000 & 0.5 & 1.196 & 0.8 \\
\hline September & 1.788 & 0.6 & 1.500 & 0.7 \\
\hline October & 1.643 & 0.6 & 0.950 & 1.1 \\
\hline November & 1.853 & 0.5 & 1.117 & 0.9 \\
\hline December & 1.867 & 0.5 & - & - \\
\hline
\end{tabular}


and their degrading effects on SSCs, while maintaining the principle that radiation exposure of inspection personnel should be kept as low as reasonably achievable. Particular consideration should be given to SSCs that are difficult to inspect or maintain.

\section{APPENDIX III: Ageing of mechanical system APPENDIX IIla: Control rod drive mechanism}

The old control rod drive mechanism has been replaced with a newer version since August 2009 as shown in Fig. 3 below. The installation was performed by the maintenance staff of GHARR-1. The procedures for replacement activities were approved by the regulatory authority (IAEA, 2010; Wogman et al., 2005).

Fig. 3

The new and old control rod drive mechanism

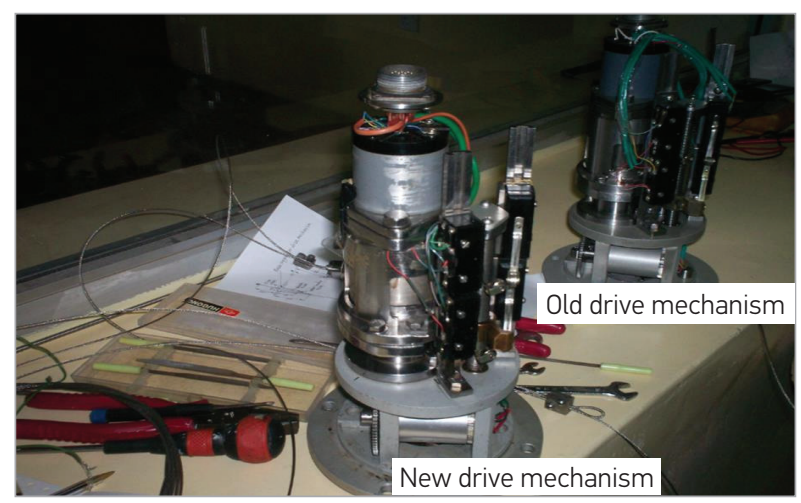

\section{APPENDIX IIIb: Activities carried out}

\section{A. Measurement procedure}

Measurements were made for the new control rod drive mechanism between:

1 the drive wheel and the first clamping block;

2 the drive wheel and the second clamping block;

3 the second clamping block and the plumb of the control rod.

It was realized that some maintenance work carried out on the old control rod drive mechanism had altered the length of the wire rope but it still did function normally. Hence, the need for its replacement was approved by the NNRI after it was suggested by the RSC.

B. Replacement procedure

1 Radiation monitoring was conducted to ensure health safety of personnel.
2 The old control rod drive mechanism was disengaged and the control rod removed and allowed dissipating off its radioactivity overnight.

3 The whole setup of the new control rod was then placed in the reactor core after all required measurements had been adhered to and the drive mechanism had been configured. The drive mechanism was then tested by fixing it on the reactor.

4 On switching the console, the rod position indicator on the console moved to $140 \mathrm{~mm}$ instead of zero. The console was switched off and the two autosyns (the transmitter and the receiver) were synchronized by readjustment of the dial on the receiver).

5 The console was switched on again and the dial remained at the zero position.

6 The flux builds up was then tested for at a preset value of $1 \times 10^{9} \mathrm{n} /\left(\mathrm{cm}^{2} \mathrm{~s}\right)$. The rod then lifted to $230 \mathrm{~mm}$ to allow for the flux build-up. On removing the first cadmium capsule, there was no significant flux build-up. This remained so until the fourth capsule was removed.

7 After the removal of the cadmium capsules and string from the inner site of the reactor, the flux build-up was found to be extremely slow. Also, after the completion of the flux build-up process, the control rod position indicator showed that the control rod position did not drop but remained at a high value.

8 It was concluded that the length of the rope wire was too long to allow the normal operation of the control rod drive mechanism. The reactor was shut down again and the cadmium string and capsules were sent back into the reactor. To determine how much wire rope was to be removed, the base of the control rod drive mechanism was packed with $15 \mathrm{~mm}$ thick wood while ensuring that the rod was still in its guide and the reactor was operated. There was a noticeable change in the rate of flux build-up although it was still too slow. The procedure was repeated with $25 \mathrm{~mm}$, $40 \mathrm{~mm}$ and finally $70 \mathrm{~mm}$ thick wood. At $70 \mathrm{~mm}$, the rate of flux build-up was found to be normal.

9 The necessary adjustments to the wire rope were made (i.e., $70 \mathrm{~mm}$ of wire rope was removed) and the control rod drive mechanism was placed on the reactor. The reactor was operated as usual at $1 \times 10^{9} \mathrm{n} /\left(\mathrm{cm}^{2} \mathrm{~s}\right)$, the cadmium strings and capsules were removed and the flux build-up now appeared normal. 
10 The reactor was shut down and operated again the next day to ensure that its operation remained normal.

11 The installation of the new control drive mechanism started on $4^{\text {th }}$ August 2009 and completed on the $19^{\text {th }}$ August 2009.

12 The new dimension set-up of the new control rod drive mechanism was shown in Fig. 3.

\section{Challenges}

It was obvious that the design of the new control rod drive mechanism was different from the old one. Hence new measurements had to be taken and adjustments made where necessary. In doing this, the original design measurements of the old drive mechanism were used to configure the new one since it did not have any accompanying document to assist in its installation.

After the detection of the slow build-up of flux, measurements were then taken for the mass and length of the plumbs of both the new and the old control rod. It was realized after taking the measurements that both the length and mass of the plumb of the new control rod assembly fell short significantly of the old control rod assembly. The length of the new plumb was $180 \mathrm{~mm}$ while that of the old was 218 $\mathrm{mm}$. Of much interest was the mass of the new rod, which fell short of the $1 \mathrm{~kg}$ standard used in most literature concerning the reactor. Whereas the plumb of the old control rod had an average mass of 824.48 $\mathrm{g}$, the plumb of the new control rod had an average mass of $640.30 \mathrm{~g}$. So, we were compelled to use the old plumb to ensure prompt scram of the reactor.
As a result, the end of the wire rope of the new control rod drive mechanism was knotted in such a way that it could be accommodated by the old control rod assembly.

All procedures carried out were done with careful adherence to all safety measures put in place for the particular type of exercise. The new control rod drive mechanism has thus been successfully installed while maintaining the old control rod in the reactor setup. The measurements taken before and after installation are captured in Table 4.

\section{APPENDIX IV: Construction of slant tube}

The existing irradiation sites accommodate only small plastic capsules which contain experimental samples. In order to experiment larger samples, a slant tube with a larger diameter was constructed to enable the irradiation of larger samples. The existing two (2) slant tubes developed some holes and were removed. The guide tube was constructed using aluminium sheets which was molded into a cylindrical tube and joined together by an electrical welding. The tube is $15 \mathrm{~cm}$ in diameter and total length of $540 \mathrm{~cm}$ (IAEA TECDOC-636, 1992). A plunger of aluminium material was designed and molded to be plugged into the tube. The dimension of the plunger is $150 \mathrm{~cm}$ by $18 \mathrm{~cm}$. Lead was melted and put in the lower part of the plunger at $20 \mathrm{~cm}$ from the bottom likewise the cover at $3 \mathrm{~cm}$ from the top. The lead was used to prevent the possibility of radiation escaping into the reactor hall during operation. The tube was fixed $20 \mathrm{~cm}$ from the reactor vessel on a stainless-steel plate of the following dimensions: thickness was $1.5 \mathrm{~cm}$, length was 105

\section{Table 4}

Measurements before and after installation

\begin{tabular}{c|c|c|c|c}
\hline \multicolumn{5}{c}{ Before the installation } \\
\hline Rise time & Falling time & $\begin{array}{c}\text { Criticality } \\
1 \times 10^{9} \mathrm{n} /\left(\mathrm{cm}^{2} \mathrm{~s}\right)\end{array}$ & $\begin{array}{c}\text { Half power }(15 \mathrm{~kW}) \\
5 \times 10^{11} \mathrm{n} /\left(\mathrm{cm}^{2} \mathrm{~s}\right)\end{array}$ & Build-up time \\
\hline $28 \mathrm{secs}$ & $28 \mathrm{secs}$ & $125 \mathrm{~mm}$ & $154 \mathrm{~mm}$ & 3 mins 20 secs \\
\hline \multicolumn{5}{|c|}{ After the installation } \\
\hline
\end{tabular}


$\mathrm{cm}$ and width was $33 \mathrm{~cm}$ bolted onto the two I-beams stretched over the pool. The tube was fixed closed to the lower vessel of where the reactor is seated at a distance of $5.0 \mathrm{~cm}$ (IAEA TECDOC-636, 1992).

\section{APPENDIX IVa: Experimental procedure for guide tube installation}

The reactor was operated under automatic mode at the neutron flux of $1 \times 10^{9} \mathrm{n} /\left(\mathrm{cm}^{2} \mathrm{~s}\right)$ to obtain the core excess reactivity. The inlet and the outlet temperatures were recorded at this flux value. Gamma radiation on top of the reactor was also recorded before the installation. Four cadmium rabbits and a string were pumped into the inner irradiation sites to ensure sub-criticality of the reactor. The slab holding the old guide tube was removed and a new one fixed. The guide tube was lowered with the help of a 5 tonnes crane fixed in the reactor hall through $18 \mathrm{~cm}$ hole in the slab and bolted it firm in position. The cadmium rabbits and the string were pumped out and the reactor operated at the same neutron flux to ensure the stability of the reactor. After 12 min of reactor operation when the slant tube was installed, there was an increase in the gamma dose at the top of the reactor vessel. This could be attributed to the interaction of air molecules with charge particles in the slant leading to the emission of radiation.

\section{APPENDIX V: Refurbishment of deionized water plant}

The facility is designed for production of deionized water (light water) to top up the reactor and the pool water respectively (IAEA, 2011). The main design parameters to be satisfied for providing quality deionized water for the miniature reactor are:

Water flow: $0.5-0.7 \mathrm{~m}^{3} / \mathrm{h}$

Conductivity $\leq 1 \mu \mathrm{S} / \mathrm{cm}$

$\mathrm{pH}=6.0 \pm 0.5$

The content of ions such as $\mathrm{Fe}^{+3}, \mathrm{Cu}^{+2}, \mathrm{Cl}^{-}$is less than $0.1 \mathrm{mg} / \mathrm{L}$.

Fig. 4 below shows the flow chart for processing of the light water for the miniature reactor.

The resins in the plant columns were replaced in December 2012. The pipes and the valves were also replaced in November 2012 as a result of brittleness due to ageing. The columns were sprayed (repainted) to mitigate corrosion. The resins were regenerated twice, in 2005 and 2010.

\section{Fig. 4}

Flow chart of pure water processing
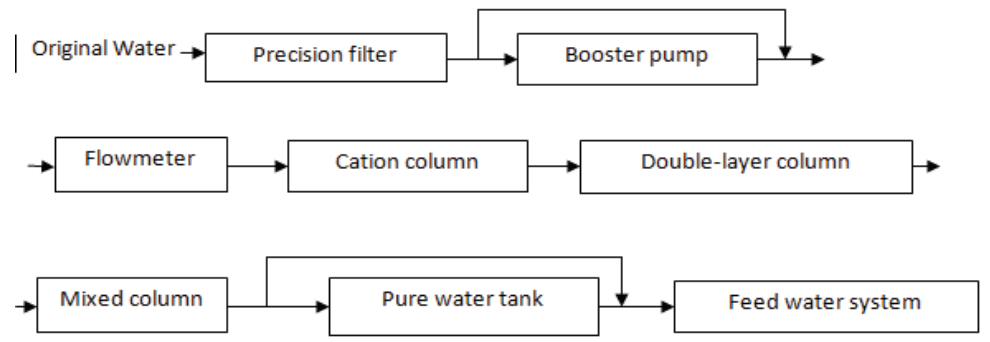


\section{Gana tyrimo reaktoriaus-1 (GHARR-1) apžvalga, susijusi su nusidèvèjimo problemomis ir jų mažinimo būdais}

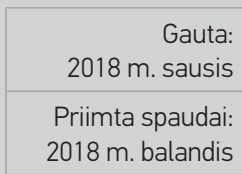

\section{F. Ameyaw}

Branduolinės inžinerijos katedra, Branduolinès ir susivienijimo mokslo magistro mokykla, Ganos universitetas, Gana

\section{R. G. Abrefah, E.O Amponsah-Abu}

Branduolinių reaktorių mokslinių tyrimų reaktoriai, Nacionalinis branduolinių tyrimų institutas, Ganos atominès energijos komisija, Gana

GHARR-1 įrenginys yra mažas neutrony šaltinio reaktorius, kurio vardinè galia yra 30 kW. "GHARR-1" buvo užsakytas 1995 m. Kovo 8 d. 19 metu eksploatavimas buvo vykdomas naudojant mikrokompiuterio uždaro ciklo sistemą (MCCLS) ir valdymo pultą (CC). Su amžiumi susijęs degradacinis efektas branduolinių reaktorių su sauga susijusiose sistemose yra valdomas taip, kad būtų išvengta, kad saugumo ribos mažetų neviršijant leistinų ribų, numatytu reaktorių projekte. Todè šiame dokumente pateikiama nauja informacija apie GHARR-1 struktūru, sistemy ir komponentu (SSC) senejjimo saugos aspektų valdymą. Tyrimo "reaktorių senejimo" saugos aspektų valdymui reikalingas aktyvaus, sistemingo ir integruoto senejimo valdymo metodas, kuriuo koordinuojamos visos su GHARR-1 gyvavimo ciklu susijusios veiklos, susijusios su SSC senejjimo blogejjimu, kontrolè, stebėsena ir sušvelninimas. Šiame dokumente pateikiama senejjimo valdymo programa ir sušvelninimo veiksmai. Senejjimo valdymo strategijos apima periodines saugos peržiūras, sudedamuju dalių ir įrenginių pakeitimo projektavimo ypatybes ir paveldejimo planavimą. Dalijimasis informacija su kitomis veikiančiomis organizacijomis yra viena iš priemonių, kurias "GHARR-1" laiko geriausiu siekiu. Šiame straipsnyjer dar kartą smulkiai apžvelgiama ir integruojama informacija, sukurta kitais senejimo valdymo tyrimais, ir kita turima informacija, susijusi su su amžiumi susijusių degradacijos padariniu suvokimu ir valdymu.

Raktiniai žodžiai: struktūros, sistemos ir komponentai (SSC), integruota grandinè, GHARR-1, lyginamoji grandinè. 